\title{
Towards a theoretical framework for human performance modelling within manufacturing systems design
}

\begin{abstract}
The performance of direct workers has a significant impact on the competitiveness of many manufacturing systems. Unfortunately, systems designers are ill-equipped to assess this impact during the design process. An opportunity exists to assist designers by expanding the capabilities of popular simulation modelling tools, and using them as a vehicle to better consider human factors during the process of manufacturing system design. To support this requirement, this paper reports on an extensive review of literature that develops a theoretical framework which summarizess the principal factors and relationships that such a modelling tool should incorporate.
\end{abstract}

\section{Keywords}

Manufacturing, human factors, modelling, simulation, theoretical framework

\section{Introduction}

The design and re-design of manufacturing systems is a challenging activity. The competitive environment is constantly changing and there appears to be an insatiable demand to make products cheaper, better and faster. In this environment, people who carry out somewhat repetitive manual production tasks seem to remain key to success (Womack et al. 1990, Parker and Wall 1996). 
Although this importance is widely recognized (Jaikumar 1986, Womack et al. 1990), the factors which affect performance are less well understood. This is particularly an issue within the process of manufacturing system design (Baines and Kay 2002). Designers of manufacturing systems often have a scant appreciation of the wide range of factors that influence the performance of the people who work within their factories. This can lead to their subsequent designs not performing as expected, with the engineer frequently overestimating how efficiently or effectively people will work. Some compensation can be made by taking a conservative view of likely system performance, but this is a poor substitute for properly understanding the factors that determine such performance.

A key challenge in manufacturing system research is to improve the awareness of engineers about the impact that human factors have on their designs (Barroso and Wilson 1999, Bonney et al. 2000). It is particularly desirable to improve this awareness early on in the design process, as many factors can be easily and inexpensively modified at this stage. One tool for improving this awareness is computer based simulation modelling (Baines and Kay 2002, Baines et al. 2003). This technique is a popular and attractive aid to designers, currently allowing them to experiment with many system variables including, for example, the number of people working on a production line, their shift patterns and task priorities. If the capability of modelling can be further developed to enable assessment of some of the more significant human behavioural factors, this 
would be a valuable means of stimulating further consideration of these factors during the design process.

The work described in this paper has, therefore, set out to develop the foundations for a modelling tool that enables the assessment of key human factors early in the process of manufacturing system design. This theoretical framework has been formed through an extensive search and synthesis of literature from a variety of sources. Described within this paper is the process used to form the framework, the framework itself, and how this can now enable the construction of practical tools for engineers. The final sections describe future research that can now be based around this framework.

\section{Background to the research}

\subsection{An appreciation of the industrial problem.}

Highly efficient production systems remain central to enabling cheaper, better and faster product manufacture (Slack et al. 2001). However, the archetypal mass production system of Henry Ford is rarely seen in practice. Market pressures translate into ever increasing demands for wider product variety, customization, faster delivery, improved quality and reduced cost (Jaikumar 1986). Consequently, the modern flow-line production system is an attempt to identify some similarities in product manufacture and to impose structure and routine into these complex systems. For example, anecdotal evidence suggests that within a typical automotive factory as many as 5000 different permutations in product specification may be produced on a flow-line production system. In this situation manufacturing system design is an onerous task, yet such systems 
must be re-designed every time a new product is introduced. Levels of financial investment can be immense (multi million pound), and the consequences of poor design can be significant. If a system fails to perform as expected, it can cause severe tension between planners and operators, and can lead to failure of the host organization. Many tactics can help to reduce the extent of failure, such as building excess capacity into a design, involving system operators in the design process, and employing computer based modelling techniques such as Discrete Event Simulation (Baines and Kay 2002).

Simulation is very popular in industry. It allows computer based models to be constructed that emulate the behaviour of the proposed system (Robinson 1994). The software is easy and fun to use and small models can be constructed relatively quickly. However, simulation models can appear credible even when performance predictions are unrealistic (Baines 1994). Such errors depend on many factors, such as the competence of the user and the complexity of the real system being modelled. One particular issue is the assumption that workers within factories are highly predictable and standardized in their behaviour. For example, model builders (who are frequently engineers), tend to assume that workers always start work on time, operate at a constant rate throughout the day, take breaks at planned times etc.

Such regular behaviour of workers rarely occurs in practice. Figure 1 is a time series showing how the cycle time performance of a manual workstation varies. These are actual times taken from a real engine assembly operation within a UK based automotive manufacturing organization. The data were gathered 
electronically over 12 weeks, and this particular figure illustrates a typical 8 hour production slot. Each data point shows the cycle time performance of an individual worker, and each cluster represents different operatives at the work station. Hence, the time series shows the extent to which performance varies for workers, and across workers, for a typical work station throughout an eight hour shift. Also evident in this graph are the operator break times, which also vary from those planned. Analysis of the data suggests that up to one third of the potential time for production is lost due to stoppages, extended breaks and disruptions to the flow of the line, many of which may be caused by worker behaviour. In this study, such variance was apparent across several workstations throughout the twelve week observation period. In this same plant, we also observed that the simulation models used to aid the design process typically over estimated assembly line performance by 15 to $20 \%$. An important factor in this gap between real and anticipated performance of the system is undoubtedly the assumption that worker performance is somewhat standardized, which as figure 1 illustrates is not the case in practice.

\section{Insert figure 1 about here}

A desirable improvement to simulation would be a more realistic representation of variations in human performance and ideally the human factors which influence these variations. Baines and Kay (2002) show how such a capability could be provided through a Human Performance Modelling tool that integrates with computer based simulation, to support the process of manufacturing system design. This is illustrated in figure 2. Development of such a capability would 
have two principal benefits. First, it would enable the creation of more valid models of manufacturing systems which would allow investment decisions to be made with greater confidence. Second, by enabling a greater consideration of human factors earlier in the systems design process, it would encourage designers to create working environments which are more sympathetic to high performance of the work force.

\section{Insert figure 2 about here}

Improving simulation, however, is not simply a challenge to the information technology and computer programming community. Currently available simulation tools, such as Witness (Robinson et al. 2001), are quite capable of representing a probability distribution of human performance. The challenge is rather; to understand precisely where a variation in human performance should be considered in a model of a manufacturing system; to appreciate the nature of such variation; and the factors that affect and amplify this variance. Therefore, a first step in creating a human performance modelling capability is to determine a theoretical framework that relates the performance of workers directly involved with manufacturing tasks, with the key factors that influence this performance. Developing such a framework is the topic of this paper.

\subsection{A review of current theoretical frameworks}

A variety of theoretical frameworks currently exists, and though none of these is tailored to the modelling challenge being addressed, they provide a valuable insight into the form a suitable framework may take. An overview of these frameworks is given in table 1 . The table details a multi-disciplinary collection of 
frameworks that show how a wide range of interrelated physical and psychosocial factors have been related to work performance outcomes pertaining to the worker, the organization and the work environment. Importantly, the table also demonstrates that attempts have already been made to account for this wide range of factors in more elaborate theoretical models, and in some cases to integrate these within frameworks for computer simulation modelling of human performance.

Many of the existing frameworks are quite general in nature. One of the best known generic frameworks was provided by Lewin (1935), who related the behaviour of the individual to their environmental context and their individual characteristics. Although this provides an excellent illustration of the scope of factors and categories that need to be accounted for, it is too vague and broad for direct application. Simlarly, Bonney et al. (2000) emphasizes the centrality of direct workers to design outcomes in their framework but do not specify the human factors that should be considered. On the other hand, more elaborate models e.g. Das (1999) and Parker et al. (2001) do put forward more specific psychosocial and physical factors relating to the person and the organization, but their variables are often indefinable and intangible constructs that would be difficult to quantify / evaluate in practice. A regular feature of these frameworks is that they neglect to fully consider aspects of the physical environment, which can be an important consideration within many factories.

On the other hand, more specific models that concentrate on particular antecedent variables or on specific behavioural outcomes are limited in scope. 
For example, Furnham's (1992) model proposes five basic categories of 'individual' factors (personality, intelligence, demographics, motivation, and ability) that influence general 'occupational behaviour'. However, by not accounting for effects of external factors (organizational / environmental), or specifying the nature of particular factors within these categories (e.g. personality type, gender, $I Q$, etc.), the model cannot be extrapolated to represent specific performance antecedents or outcomes. It is, therefore, of limited practical use in the representation of person-performance relationships in particular situations or contexts - such as a manufacturing system.

In respect of models that are particularly related to the manufacturing system context, Miller and Swain's (1987) inventory of 'Performance-Shaping Factors' addresses a range of relevant environmental, organizational and individual factors. However, these are only considered in relation to error-related performance outcomes. Toriizuka (2001) has elaborated the Miller and Swain performance shaping factors framework to improve work style, work efficiency and the comfort of work in the field of human reliability. This model is, unfortunately, specifically for maintenance tasks which have their own unique characteristics. Similarly, whilst Stone and Eddy's (1996) factors are also explicitly relevant to the manufacturing context, and reinforce the positive effects of person-organization fit, the framework is not directly suitable because it was specifically developed for only quality-related performance outcomes. This model also does not account for physical environment factors. 
A framework which focuses specifically on organizational factors was developed by Ichniowski and Shaw (1999). They identified a set of Human Resource Management (HRM) techniques which they considered to be typical of Japanese manufacturing firms (job rotation, communication, orientation, payment systems, teams, recruitment/screening and training). They then classified the HRM systems of 36 US steel finishing lines in terms of their adoption of these practices as 'traditional', 'low teamwork and communication', 'high teamwork and communication' and 'innovative'. They used regression analysis to relate the use of these practices to production, and found that the US firms with 'innovative' HRM practices had uptime and product quality equivalent to that of the Japanese firms, while the 'traditional' US lines showed the worst relative performance. However, the disadvantages of this framework (from the point of view of our current study) are that it only includes HRM practices, ignoring other organizational and physical environmental factors, and that its performance measures are related to overall line performance rather than the effects on the behaviour of individual workers.

Existing frameworks that have been developed specifically for computer-based human performance simulations include the Integrated Performance Modelling Environment (IPME) framework co-developed by DERA Centre for Human Sciences (UK), Micro Analysis and Design (US) and Defence and Civil Institute Environmental Medicine (Canada) (Dahn and Laughery 1997, Bunting and Belyavin 1999). This framework aims to represent human performance in complex environments within computer-based Discrete Event Simulation (DES) 
models using data drawn from empirical studies in the literature and from many military laboratory based studies. However, although the framework accounts for physical environmental factors it is mostly concerned with system performance as an amalgamation of individual performance and ignores the interaction and mediating effects of other variables (e.g. organizational) by applying 'micro models' in an additive manner. Alternatively, whilst the PECS (Physical conditions, Emotional state, Cognitive capabilities, Social status) (Schmidt 2000) human performance modelling framework does account for physical and social / organizational environments, it represents human processes and performance in social systems via group behaviours using autonomous agents. Thus, the generic framework does not, once again, provide a model of factors and functional relationships relevant to the performance variables of a manufacturing work environment.

These frameworks exemplify the current research problem. Clearly, there is a need for a simple framework which encapsulates the multitude of human factors that need to be considered in manufacturing systems. Parker et al. (2001) assert that a universal list of factors would probably be infinite - but that it should be possible to identify categories of variables in an 'overall guiding theoretical framework' that could be adapted and applied differently according to context. The challenge for this research is to create such a guide that will be specifically appropriate to manufacturing system simulation. 


\section{Research aim and methodology}

\subsection{Overview of research aim and methodology}

The aim of the research described in this paper has been to form a theoretical framework that will enable human performance modelling within the process of manufacturing system design. At this stage in our research we have limited our scope to 'direct workers' (Greener 1994), those people who carry out the somewhat manual tasks within production, but whose activity is critical to the overall performance of a facility. To achieve the aim, two principal questions are immediately apparent. First, what are the appropriate direct worker activities and associated performance measures on which a framework should be based? Second, what factors are most likely to have an impact on these measures?

The research methodology was structured to address each of these questions in turn. The first stage investigated the ways in which a typical DES tool currently deals with direct workers. A typical commercial modelling tool was studied in detail, the procedure used to represent direct workers was assessed, and from this the required measures of variations in human performance were identified. This approach is explained further in section 3.2.

The next step was then to identify the human factors which are most likely to have an impact on these metrics in practice. As many potential factors exist Parker et al. 2001), a method of screening and ranking possible factors was designed. This method included an assessment of whether a factor was relevant to the performance metrics, whether it was measurable, and the probable extent to which it would affect worker performance. An extensive literature search was 
then conducted to identify possible factors. The starting point for the investigation of the factors was based on Kurt Lewin's field theory (Lewin 1935). Field theory, which is a very open framework, regards individual behaviour as the outcome of a dynamic system, in which factors relating to the individual interact with elements of the environment, as shown in figure 3 . To guide this review, the literature search was structured around factors relating to the individual and the working environment. On completion of this analysis, the factors and performance measures were brought together to form the framework. Section 3.3 describes this procedure in greater detail.

\section{Insert figure 3 about here}

\subsection{Procedure used for identifying relevant measures of direct worker performance.}

The first stage in the research was to determine the appropriate measures of direct worker performance; in other words where within a simulation model of a manufacturing system should distribution in human performance be considered? Witness (Robinson et al. 2001) was chosen as a representative modelling tool, this is based on the technique of DES and is very popular within industry. On investigation it became apparent that within this tool a rather mechanistic approach is taken to modelling workers, for example:

-When workers are available in a model, they can be instantaneously 'called' by machines and will instantaneously respond unless they are held back by another machine. 
-When called to a machine, the workers then perform at a constant rate.

- On completion of a task, a worker is 'released' and will instantaneously be available to other resources.

- No production errors are attributed to the worker.

Although each of these assumptions is a rather simplified view of worker behaviour and performance, three important points must be stressed. First, Witness is not unusual in the manner the tool treats workers; rather, we consider this to be a very capable and credible product. Second, these limitations are not simply a software limitation; rather, they illustrate a fundamental lack of knowledge about worker interactions and performance. Finally, representing workers in this simplistic way, may only be an issue when model accuracy is of upmost importance. Sometimes a model may be constructed simply to illustrate a system in operation. Only when model accuracy is critical is a more realistic representation of human performance necessary. In this situation however, the following considerations of human performance need to be incorporated in tools such as Witness:

- Dependability distribution: Given that all conditions for a worker to begin a task are met, what delays occur prior to an operator responding to instructions to start work?

- Activity time distribution: after a worker has started a task, how will the activity time vary? 
- Error rate distribution: how accurately and reliably does an operator carry out a task? Errors are any deviation from product specification, which may result in unserviceable product ('scrap') or product which requires additional processing to become serviceable ('rework').

In addition to addressing these three major variations in worker performance, if a model is run over an extended period other issues that should also be considered include:

- Absenteeism rate: how consistent does a person participate in the work activity over an extended period? Absence from the workplace can occur for many reasons such as official leave, such as allowances for child birth, bereavement, training etc, as well as statutory sick leave.

- Accident rate: how safely does an operator carry out their work? A number of accident types can be identified, e.g. those caused by human error that result in personal injury, and those caused by human error that result in damage to plant, buildings, or equipment.

- Staff turnover rate: How constant is worker engagement? The number of employees starting (or finishing) employment at a particular place of work over a given period, and the associated impact of 'green' labour.

On this basis, there are six important variations in human performance that ought to be considered in a model of a manufacturing system. In the remainder of this paper we refer to these as the Human Performance Variation Metrics, and move on to explore the key factors that affect these. 


\subsection{Procedure used for identifying key human related factors}

The second stage of the research was to identify those key human related factors which are most likely to cause variation in the six human performance variation metrics. As outlined in section 3.1, the approach taken to identifying these key factors was first to conduct a large scale identification of relevant literature, and then to apply a method of screening. The literature search was carried out in a variety of areas, including manufacturing management, applied psychology, social psychology, ergonomics, human factors, behavioural medicine, applied physiology, health and safety, environmental medicine, management science, organizational studies, economics, industrial relations, human resources management and occupational psychology. Over 800 references were considered overall. Each of these papers was in some way concerned with a factor which has been found to have some impact on human performance. Each paper was then screened on the basis of the following four criteria:

- General relevance: Is there evidence in the paper that the factors considered are related to the performance of people conducting manual and repetitive activities?

- Specific relevance: Is the factor related to manual production work and/or likely to be directly related to the human performance variation metrics?

- Robustness: Is the literature consistent in terms of the impact of the factor? Are the sources quoted reliable and based on credible, robust empirical studies? 
- Measurability: Can the factor be reliably and consistently assessed?

The screening was carried out by assessing each paper in turn against the four criteria outlined above. Once an initial screening had been made to reduce the range of papers being considered, a secondary assessment was then conducted to score and rank papers. The scoring process was based on a scale of $0-4$. Here a score of ' 4 ' meant that the factor satisified the factor very well, and where ' 0 ' meant that the factor did not satisfy the criteria in any way.

This screening identified a total of 65 potential factors for inclusion in the theoretical framework. These fell into three categories; factors relating to the individual worker, factors relating to the physical working environment, and factors concerned with the organizational working structure. In the remainder of this paper we refer to these as the key human centred factors. These combine with the human performance variation metrics to give the outline of modelling capability. The actual factors chosen is given in table 2, with an overview of the debate involved in each case given below.

\section{Key human centred factors}

This section gives a summary of the considerations made in each of the three categories of key human centred factors.

\subsection{Factors about the individual.}

Factors in the literature relating to the person themselves comprised a diverse range of 'state' and 'trait' variables spanning six major categories: personality, demographics, physiology, cognition, motivation and skills. They can relate to performance in a number of ways. For example, 'trait' cognitive ability can 
contribute directly to overall job performance, in all areas of work, through its effects on knowledge and skills acquisition (Ree et al. 1994). Similiarly, motivation 'states' such as job satisfaction have been found related to performance via job characteristics (Hackman and Oldham, 1976).

The process of assessing these factors was complex and extremely difficult. Some factors performed well against the screening process. Here, the intelligence factor 'general cognitive ability' (' $g$ ') and the personality dimension of 'conscientiousness' scored most highly across the scoring criteria, being straightforward to measure and supported by robust literature indicating that these are the factors most strongly related to work performance (Viswesvaren and Ones 2000) for both individual and organizational outcomes (Miller et al. 1999). Other personality traits scored highly for being easily measurable and related to work performance, although this tended to be in relation to specific types or aspects of work, for example interpersonal skills (Mount et al.1998), training (Barrick and Mount 1991), and turnover (Barrick et al. 1994). In addition to 'trait' characteristic variables, several 'state' and attitudinal factors scored highly for being associated with work performance via motivations. For example, organizational commitment (Van Scotter 2000, Suliman and lles 2000) and job satisfaction (Hackman and Oldman, 1976) scored particularly highly across the criteria, followed by a variety of combined work-related attitudes and beliefs. However, although basic demographics, such as age and gender, could be scored highly in terms of measurability and relevance to work performance (Ilmarenen 1994), most of the demographic and physiological factors received 
very low scores against the selection criteria. This was because certain factors were supported by little evidence to suggest a relevance to manufacturing productivity and / or were found particularly difficult to measure.

\subsection{Factors about the physical environment}

Physical environmental factors in the literature cover the areas of noise, vibration, light and indoor air quality (including air temperature and humidity). For example, considerable literature has existed for sometime that observes the impact of noise level upon performance measures such as productivity (Weston and Adams 1932), error rate (Broadbent and Little 1960, Nowier 1984) and accidents (Heald 1955), depending on the nature of the task (Levy-Leboyer and Moser 1988). Another factor relating to the physical working environment is indoor air quality, which has been identified by the US Government Environmental Protection Agency as potentially more significant in its health effects than outdoor air pollution (EPA 2001). The effects on workers of different chemical species of air pollution have been researched, for example carbon dioxide (Scheff et al. 2000), carbon monoxide (LaBar 1991) and ozone (Gliner et al. 1980).

During the screening process, the results were sometimes quite surprising. For example, there was evidence from the literature that noise affects general worker performance (Glass and Singer 1972), but the evidence was not overly robust, being dependent on a single paper only. Research into the effects of vibration, on the other hand, is relatively extensive (e.g. Griffin and Lewis 1978, Fahy and 
Walker 1998, Jones 1992), but largely inconclusive (Oborne 1995, Griffin and Lewis 1978) and highly context specific.

Air temperature is also clearly significant, with extensive literature to support its relevance. For example, U.S.DOHHS, 1992, Meese et al. 1984 and Parsons, 2000 , all demonstrate effects of temperature or humidity upon performance at work. Equipment for measuring temperature is also easily available, making the process of gathering data on temperature relatively simple. Light level is another significant factor and several cases identify the potential benefits and pitfalls that can be achieved from various lighting levels at work (e.g. Steelcase 1999, Dul and Weerdmeester 1993 and Gilbert and Hopkinson 1949). Measuring and recording light levels is also relatively easy to carry out.

\subsection{Factors about the organizational environment}

Organizational environmental factors relate to organizational structure, culture and human resources practices. Structural factors such as shift work (Monk and Folkard 1992) and organizational hierarchy (Woodward et al. 1965) have been widely studied and established as affecting worker productivity. Changing attitudes to the management of manufacturing systems in the last two decades of the twentieth century have led to an increasing awareness of the importance of human resources management (Snell and Dean 1992) and a large number of empirical studies of the effectiveness of policies relating to worker empowerment, such as team working (Knights 2000), training (Barrett and O'Connell 2001) and recruitment (Ichniowski and Shaw 1999). 
A number of organizational factors were rejected through screening. For example, from the literature it can be seen that the impact of payment systems on worker productivity is controversial. Some authors argue that pay is more often associated with factors such as job level and seniority than performance (Lawler 1975), and that incentive schemes rarely have the desired effect and may be counter-productive (Kohn 1993), although others dispute this (Luthans and Stajkovic 1999). In addition, the effectiveness of payment schemes may be hard to measure, because they apply to the workforce as a whole, and hence their impact on individual worker performance cannot be evaluated. This difficulty also applies to other organizational factors, such as recruitment and employment security.

A most significant organizational variable is shift work, the effects of which are documented by a considerable literature (e.g. Monk and Folkard 1992, Akerstedt and Landstrom 1995, Hossain and Shapiro 1999, and Marquie and Foret 1999). This factor can be 'measured' by comparing variations in productivity between different shifts. Team working is also important (see e.g. Kolasa 1975, Ichniowski and Shaw 1999, Dunphy and Bryant 1996), and the effects may be measured by looking at differences in productivity between teams.

\section{Formation of the theoretical framework}

The screening of factors involved a degree of subjective judgement, particularly in assigning values for the scores and in ranking. This was inevitable given the nature of the problem. However, the process that was followed provided a way 
of making the subjective judgements explicit and thus open to review. Scores were assigned, discussed and reviewed by members of the research team, rather than a single individual, to ensure that a convincing case could be made for each score. In the absence of a more objective method of assessing the factors, this was felt to be the most satisfactory approach available. The ranking of human centred factors then provided a basis for the formation of the theoretical framework. The inventory of ranked factors, however, still consisted of 65 potential variables, which was considered to be too many for inclusion into a framework which would eventually be used in practice. Consequently, the ranking was examined carefully and a clear cut-off point was established by looking for natural groupings, especially against the criteria of relevance and measurability. In this way, thirty key factors were finally identified, and these are shown in the shaded area of table 2.

\section{Insert table 2 about here}

The key factors identified by this process provide a comprehensive picture of the factors that are most likely to influence a person carrying out production tasks. These factors range from the individual's personality, intelligence and demographic characteristics to the physical setting of the workplace and the characteristics of the organization. The original framework derived from Lewin's model, as illustrated in figure 3, was first expanded using the three sets of key human centred factors, and then expanded further to include the human performance variation metrics established in section 3.2. This is illustrated in figure 4 . 


\section{Insert figure 4 about here}

The theoretical framework offers a qualitative representation of the determinants of worker performance. The final element of the theoretical framework is the set of functional relationships, which describe the effects on the performance measures of changes in the key variables. At this stage of our research, it is only possible to offer hypothetical relationships between the key factors and the performance measures, of the generic form shown in equation (1), where $\Delta \mathrm{V}_{\mathrm{j}}$ $(j=1-30)$ is a change in the value of a key variable and $\Delta P_{i j}(i=1-6, j=1-30)$ is the resultant change in the value of a performance variable.

$$
\Delta \mathrm{P}_{\mathrm{ij}}=f\left(\Delta \mathrm{V}_{\mathrm{j}}\right)
$$

Although the general form of some of these relationships can be gleaned from the literature (for example, the impact of age on cycle time), their precise nature has yet to be established. This therefore is the future challenge in creating a human performance modelling capability within the process of manufacturing systems design.

\section{Concluding remarks and future work}

The aim of the research described in this paper has been to form a theoretical framework to conceptually enable human performance modelling as an aid to manufacturing system design.

The next stage in the development of a modelling tool is the elaboration of the functional relationships in the manufacturing context, and the work described here will provide a structure around which such a study can be designed. The 
theoretical framework will provide a means of hypothesising the relationships that need to be sought in order to begin to form a modelling tool. This research will need to be conducted in a real manufacturing environment, and there will be several significant challenges to be overcome. For example, we may find that some of the key variables in our framework are simply too controversial to measure in practice, such as attempting to relate age, gender or IQ to performance. We may therefore be forced to consider rationalizing our framework further to make it workable in practice. Also, experiment design will need to overcome issues associated with worker performance being impacted by an intrusive experimentation procedure, classically associated with the Hawthorne Effect.

Such barriers mean that the future for research in this field is likely to be a stream of interrelated projects which incrementally develop theory and practice. The goal is simply a noble attempt to entice engineers to more carefully consider human factors, early in the design process, and using simulation as a vehicle to realise this goal. It may take a several research initiatives before even a limited modelling capability is available, and this may be based on a very much smaller set of factors than those presented in this paper. Nevertheless, the work described here is an essential step in developing this capability, as it attempts to order and prioritise those factors that clearly should be considered in the next phase of research, and those that for the moment need not be considered further. 


\section{Acknowledgements}

This research is sponsored by the Ford Motor Company and supported by EPSRC through the Innovative Manufacturing Research Centre at Cranfield. The authors would like to gratefully acknowledge the support and contribution of their colleagues, Dr Val Vitanov, Professor John Kay, Steve Mason and Peer Siebers of Cranfield University, and John Ladbrook of Ford Motor Company.

\section{References}

AKERSTEDT, T. and LANDSTROM, U, 1995, Work place countermeasures of night shift fatigue. International Journal of Industrial Ergonomics, Vol 21, pp167178

BAINES, T.S., 1994, Modelling in the evaluation of a manufacturing strategy, PhD thesis, Cranfield University, UK

BAINES, T.S. and KAY, J.M. 2002, Human performance modelling as an aid in the process of manufacturing system design: a pilot study, International Journal of Production Research, Vol. 40, No. 10, pp. 2321-2334

BAINES, T.S., HADFIELD, L., KAY, J.M. and LADBROOK, J. 2003, Human performance modelling within assembly line simulation, Industrial Simulation Conference 2003, Universita Politecnica de Valencia, Valencia, Spain, June $9^{\text {th }}$ $11^{\text {th }} 2003$

BARRETT, A. and O'CONNELL, PJ, 2001, Does training generally work? The returns to in-company training, Industrial and Labor Relations Review, April 2001, 54(3)

BARRICK, M. R. and MOUNT, M. K., 1991, The Big Five personality dimensions and job performance: a meta-analysis. Personality Psychology, 44, 1-26

BARRICK, M. R., MOUNT, M. K., and STRAUSS, J. P.,1994, Antecedents of involuntary turnover due to a reduction in force. Personnel Psychology, 47:515536.

BARROSO, MP and WILSON,JR, 1999, HEDOMS - Human error and disturbance occurrence in manufacturing systems: Toward the development of an analytical framework, Human Factors and Ergonomics in Manufacturing, Vol 9(1), pp87-104 
BONNEY, M., HEAD, M., RATCHEV, S. and MOUALEK, I., 2000, A manufacturing system design framework for computer aided industrial engineering. International Journal of Production Research, 38, 17, 4317-4327

BROADBENT D.E. and LITTLE E.A.J., 1960, Effects of noise reduction in a work situation. Occupational Psychology 34

BUNTING, A.J. and BELYAVIN, A.J., 1999, Modelling Human Performance in Semi-Automated Systems in People in control-international conference on human interfaces in control rooms, cockpits and command centres, pp21-25, (IEE CP)

DAHN, D and LAUGHERY, K. R., 1997, The Integrated Performance Modeling Environment - Simulating Human-System Performance, Proceedings of the 1997 Winter Simulation Conference, Atlanta, Georgia pp1141-1145

DAS, B., 1999, Development of a comprehensive industrial work design model. Human Factors and Ergonomics in Manufacturing, 9, 4, 393-411

DUL, J. and WEERDMEESTER, B., 1993, Ergonomics for Beginners; A Quick Reference Guide, $9^{\text {th }}$ edition, (Taylor and Francis, London.) pp. 71-97.

DUNPHY, D and BRYANT, B., 1996, Teams: Panaceas or prescriptions for improved performance?, Human Relations, 49(5)

ENVIRONMENTAL PROTECTION AGENCY (EPA), 2001, Indoor air pollution: An introduction for health professionals. http://www.epa.gov/iaq/index.html.

FAHY and WALKER, 1998, Fundamentals of Noise and Vibration. 1st edition. (Routledge).

FURNHAM, A., 1992, Personality at Work. London: (Routledge)

GILBERT M. and HOPKINSON R.G., 1949, The illumination of the Snellen chart. British Journal of Opthamology 33.

GLASS D.C. and SINGER J.E., 1972, Urban Stress: Experiments on noise and social stressors. (London and New York: Academic Press.)

GLINER J.A., HOVARTH S.M., SORICH R.A. and HANLEY J., 1980, Psychomotor performance during ozone exposure: spectral and discriminant function analysis of EEG. Aviation, Space and Environmental Medicine 54.

GREENER M., 1994 The Penguin Business Dictionary (Penguin, London)

GRIFFIN M.J. and LEWIS C.H., 1978, A review of the effects of vibration on visual acuity band continuous manual control. Part 1: Visual Acuity. Journal of Sound and Vibration 56.

HACKMAN, J.R. and OLDMAN, G.R., 1976 Motivation through the design of work: test of a theory. Organizational Behavior and Human Performance, 16, 2 250-79

HEALD L., 1955, Parliamentary Debates. 95. 
HOSSAIN,JL and SHAPIRO, CM, 1999, Considerations and possible consequences of shift work, Journal of Psychosomatic Research, 47(4), pp293296

ICHNIOWSKI, C. and SHAW, K, 1999, The effects of human resource management systems on economic performance: An international comparison of US and Japanese plants, Management Science, 45(5), May 1999, pp 704-721

ILMARENEN, J., 1994, Job design for the aged with regard to their decline in their maximal aerobic capacity, Part II: the scientific base for the guide. International Journal of Industrial Ergonomics, 10, 65-77

JAIKUMAR, R., 1986, Postindustrial manufacturing, Harvard Business Review, Vol 64(6), pp69-76

JONES D.M., 1992, Handbook of Human Performance Volume 1:The physical environment, (Academic Press Ltd, London)..

KNIGHTS, D., 2000, Bewitched, bothered and bewildered: The meaning and experience of teamworking for employees in an automobile company, Human Relations, Nov 2000

KOHN, A., 1993, Why incentive plans cannot work, Harvard Business Review

KOLASA, B. J., 1975, Social influence of groups, In Steers and Porter (eds), Motivation and Work Behavior, (McGraw-Hill, Inc, New York), Chapter 10, pp318327

LA BAR G., 1991, Hazardous Air: Monitoring Common Gases. Occupational Hazards 53, 67-71.

LAWLER, E. E, 1975, Using pay to motivate job performance, In Wexley and Yukl, Organizational behaviour and industrial psychology, (OUP, pp56-72)

LEVY-LEBOYER A. and MOSER G., 1988, Noise effects on two industrial tasks. Proceedings of Fifth International Congress on Noise as a Public Health Problem. Stockholm.

LEWIN K., 1935, A Dynamic Theory of Personality: Selected papers, Translated by D.K. Adams and K.E. Zener, (McGraw Hill Book Company Inc, London)

LUTHANS F. and STAJKOVIC, A. D., 1999, Reinforce for performance: the need to go beyond pay and even rewards, The Academy of Management Executive, 13(2)

MARQUIE J.C. and FORET J., 1999, Sleep, age and shiftwork experience, Journal of Sleep Research, Vol 8, pp297-304

MEESE G.B., KOK L., LEWIS M.I. and WYON D.P., 1984, A laboratory study of the effects of moderate thermal stress on the performance of factory workers. Ergonomics 27,

MILLER, D.P. and SWAIN, A.D., 1987, Human error and human reliability. In: G Salvendy (Ed.), Handbook of Human Factors. (New York: Wiley-Interscience) 
MILLER, R.L., GRIFFIN, M.A., HART, P.M., 1999, Personality and organizational health: the role of conscientiousness. Work and Stress, 13, 7-19

MONK T.H. and FOLKARD S., 1992, Making Shiftwork Tolerable, (Taylor and Francis, London)

MOUNT M.K., BARRICK M.R. and STEWART G.L.,1998, Five-factor model of personality and performance in jobs involving interpersonal interactions. Human Performance, 11, 145-166

NOWIER M.H., 1984, Noise exposure as related to productivity, disciplinary actions, absenteeism, and accidents among textile workers. Journal of Safety Research 15,

OBORNE D.J., 1987, Ergonomics at Work. $2^{\text {nd }}$ Edition (Wiley: New York).

PARKER S.K. and WALL T.D., 1996, Job design in modern manufacturing, In: Psychology at Work (Penguin Books)

PARKER, S.K., WALL, T.D. and CORDERY, J.L., 2001, Future work design research and practice: towards an elaborated model of work design. Journal of Occupational and Organizational Psychology, 74, 413-440

PARSONS K.C., 2000, Environmental Ergonomics: A review of principles, methods and models. Applied Ergonomics 31.

REE, M.J., EARLES, J.A. and TEACHOUT, M.S., 1994, Predicting job performance: not much more than 'g'. Journal of Applied Psychology, 79, 4, 51825

ROBINSON, S., 1994, Successful Simulation (McGraw-Hill, London).

ROBINSON, S., ALIFANTIS, T., HURRION, R., EDWARDS, J., LADBROOK, J. and WALLER, T., 2001, Modelling and improving human decision making with simulation, Proceedings of the 2001 Winter Simulation Conference

SCHEFF P.A., PAULIUS V.K., HUANG S.W. \& CONROY, L.M., 2000, Indoor air quality in a middle school, pt1: Use of $\mathrm{CO}_{2}$ as a tracer for effective ventilation. Applied Occupational and Environmental Hygiene, 15, 824-834.

SCHMIDT, B., 2000, The Modelling of Human Behaviour, (SCS-Europe BVBA, Ghent, Belgium)

SLACK, N., CHAMBERS, S. and JOHNSTON, R., 2001 Operations Management, $3^{\text {rd }}$ edition (Financial Times Prentice Hall, Harlow, UK)

SNELL, S.A. and DEAN, J.W, 1992, Integrated manufacturing and human resource management: A human capital perspective, Academy of Management Journal, 35(3)

STEELCASE (1999) Seeing the difference. Workplace issues 1

STONE, D.L. and EDDY, E.R., 1996, A model of individual and organizational factors affecting quality-related outcomes. Journal of Quality Management, $1,1,21-48$ 
SULIMAN, A. and ILES, P., 2000, Is continuous commitment beneficial to organizations? Commitment-performance relationship: a new look. Journal of Management Psychology, 15, 5, 407-26

TORIIZUKA, T., (2001) Application of performance shaping factor (PSF) for work improvement in industrial plant maintenance tasks. International Journal of Industrial Ergonomics, 28, 225-236

U.S. DEPARTMENT OF HEALTH AND HUMAN SERVICES., 1992, Working in hot environments. (National Institute for Occupational Safety and Health)

VAN SCOTTER, J.R. 2000, Relationships of task performance and contextual performance with turnover, job satisfaction, and affective commitment. Human Resource Management Review, 10, 79-95

VISWESVAREN, C. and ONES, D.S., 2000, Perspectives on models of job performance. International Journal of Selection and Assessment, 8,4, 216-26

WESTON H.C. and ADAMS S., 1932, The effects of noise on the performance of weavers, Medical Research Council Industrial Research Board Report 65.

WOMACK, JP, JONES, DT, and ROOS, D, 1990, The machine that changed the world, (Maxwell Macmillan International, Oxford)

WOODWARD, J., 1965, Industrial organization: Theory and practice, (OUP, London) 
Table 1: Theoretical frameworks relating human factors and performance

\begin{tabular}{|c|c|c|c|c|}
\hline & AUTHORS & FRAMEWORK & SYNOPSIS & TARGET APPLICATION \\
\hline 1 & Lewin, (1935) & Field theory & $\begin{array}{l}\text { Describes human behaviour as } \\
\text { determined by the interaction } \\
\text { between factors relating to the } \\
\text { individual and to the environment. }\end{array}$ & $\begin{array}{l}\text { General understanding of } \\
\text { human behaviour }\end{array}$ \\
\hline 2 & $\begin{array}{l}\text { Miller \& Swain } \\
\text { (1987) }\end{array}$ & $\begin{array}{l}\text { Performance-shaping } \\
\text { factors }\end{array}$ & $\begin{array}{l}\text { Inventory of factors that predispose } \\
\text { industrial workers to errors in } \\
\text { performance }\end{array}$ & $\begin{array}{l}\text { Human error research / } \\
\text { practice }\end{array}$ \\
\hline 3 & $\begin{array}{l}\text { Furnham } \\
\text { (1992) }\end{array}$ & $\begin{array}{l}\text { Factors predicting } \\
\text { occupational behaviour }\end{array}$ & $\begin{array}{l}\text { Specifies basic factors related to } \\
\text { occupational behaviour and their } \\
\text { interrelationships }\end{array}$ & $\begin{array}{l}\text { Research / practice } \\
\text { (general) }\end{array}$ \\
\hline 4 & $\begin{array}{l}\text { Stone \& Eddy } \\
\text { (1996) }\end{array}$ & $\begin{array}{l}\text { Factors affecting quality } \\
\text { related outcomes }\end{array}$ & $\begin{array}{l}\text { Models relationship of factors } \\
\text { pertaining to the individual and the } \\
\text { organisation }\end{array}$ & $\begin{array}{l}\text { Work improvement for } \\
\text { TQM systems }\end{array}$ \\
\hline 5 & $\begin{array}{l}\text { Dahn \& } \\
\text { Laughery } \\
\text { (1997), Bunting } \\
\text { \& Belyavin } \\
\text { (1999) }\end{array}$ & $\begin{array}{l}\text { Integrated Performance } \\
\text { Modelling Environment } \\
\text { (IPME) }\end{array}$ & $\begin{array}{l}\text { Developed for modelling the human } \\
\text { contribution to system performance }\end{array}$ & $\begin{array}{l}\text { Human performance } \\
\text { modelling for military / } \\
\text { industrial application }\end{array}$ \\
\hline 6 & Das (1999) & $\begin{array}{l}\text { Comprehensive Model } \\
\text { of Industrial Work } \\
\text { Design }\end{array}$ & $\begin{array}{l}\text { Models relationships between factors } \\
\text { involving the human, machine, job, } \\
\text { workspace and work design. }\end{array}$ & Industrial work design \\
\hline 7 & $\begin{array}{l}\text { Ichniowski \& } \\
\text { Shaw (1999) }\end{array}$ & $\begin{array}{l}\text { Human Resource } \\
\text { Management (HRM) } \\
\text { practices and } \\
\text { productivity }\end{array}$ & $\begin{array}{l}\text { A set of human resource } \\
\text { management (HRM) techniques } \\
\text { typical of Japanese manufacturing } \\
\text { firms (job rotation, communication, } \\
\text { orientation, payment systems, teams, } \\
\text { recruitment/screen }\end{array}$ & $\begin{array}{l}\text { Overall productivity of } \\
\text { Japanese and US steel } \\
\text { finishing plants }\end{array}$ \\
\hline 8 & $\begin{array}{l}\text { Bonney, Head, } \\
\text { Ratchev \& } \\
\text { Moualek (2000) }\end{array}$ & $\begin{array}{l}\text { Manufacturing System } \\
\text { Design Framework for } \\
\text { Computer Aided } \\
\text { Industrial Engineering }\end{array}$ & $\begin{array}{l}\text { Integrates product, process and } \\
\text { system design by emphasizing } \\
\text { human factors considerations }\end{array}$ & $\begin{array}{l}\text { Manufacturing systems } \\
\text { computer based design } \\
\text { software }\end{array}$ \\
\hline 9 & Schmidt (2000) & $\begin{array}{l}\text { Physical conditions, } \\
\text { Emotional state, } \\
\text { Cognitive capabilities, } \\
\text { Social status (PECS) }\end{array}$ & $\begin{array}{l}\text { Agent based modelling framework } \\
\text { Physical, Emotional, Cognitive and } \\
\text { Social effects group performance }\end{array}$ & $\begin{array}{l}\text { Human performance } \\
\text { modelling of social } \\
\text { systems }\end{array}$ \\
\hline 10 & $\begin{array}{l}\text { Parker, Wall \& } \\
\text { Cordery (2001) }\end{array}$ & $\begin{array}{l}\text { Elaborated Model of } \\
\text { Work Design }\end{array}$ & $\begin{array}{l}\text { Specifies five categories of work } \\
\text { design variables that span individual, } \\
\text { group and organizational variables }\end{array}$ & $\begin{array}{l}\text { Contemporary work } \\
\text { design }\end{array}$ \\
\hline 11 & $\begin{array}{l}\text { Toriizuka } \\
\text { (2001) }\end{array}$ & $\begin{array}{l}\text { Performance-shaping } \\
\text { factors for industrial } \\
\text { plant maintenance }\end{array}$ & $\begin{array}{l}\text { Inventory of factors that influence } \\
\text { human reliability, work efficiency and } \\
\text { workload }\end{array}$ & $\begin{array}{l}\text { Work improvement of } \\
\text { maintenance tasks in } \\
\text { industrial plants }\end{array}$ \\
\hline
\end{tabular}


Table 2: Selection of key human centered factors affecting worker performance

\begin{tabular}{|c|c|c|c|}
\hline 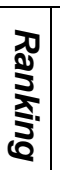 & Individual variables & Physical environment & $\begin{array}{c}\text { Organizational } \\
\text { environment }\end{array}$ \\
\hline $\begin{array}{l}15 \\
14 \\
14\end{array}$ & 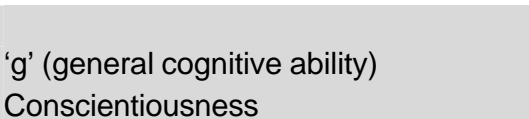 & & $\begin{array}{l}\text { Shift patterns } \\
\text { Work teams }\end{array}$ \\
\hline $\begin{array}{l}13 \\
13\end{array}$ & $\begin{array}{l}\text { Extroversion } \\
\text { Neuroticism }\end{array}$ & & $\begin{array}{l}\text { Maintenance } \\
\text { Training }\end{array}$ \\
\hline $\begin{array}{l}12 \\
12\end{array}$ & $\begin{array}{l}\text { Organizational Commitment } \\
\text { Job Satisfaction }\end{array}$ & $\begin{array}{l}\text { Noise Level } \\
\text { Air Temperature }\end{array}$ & $\begin{array}{l}\text { Job rotation } \\
\text { Communication }\end{array}$ \\
\hline $\begin{array}{l}12 \\
11 \\
11\end{array}$ & $\begin{array}{l}\text { Age } \\
\text { Work-related Attitudes, Beliefs, Values } \\
\text { Work Ethic }\end{array}$ & & Diversity \\
\hline $\begin{array}{l}10 \\
10\end{array}$ & Goals & & $\begin{array}{l}\text { Hierarchical structure } \\
\text { Climate }\end{array}$ \\
\hline 9 & Agreeableness & Light Level & \\
\hline $\begin{array}{l}9 \\
9\end{array}$ & $\begin{array}{l}\text { Openness } \\
\text { Gender }\end{array}$ & $\begin{array}{l}\text { Humidity } \\
\text { Ventilation }\end{array}$ & \\
\hline $\begin{array}{l}9 \\
9 \\
9\end{array}$ & $\begin{array}{l}\text { IQ } \\
\text { Locus of Control } \\
\text { Skills, level, ranae and experience }\end{array}$ & & \\
\hline $\begin{array}{l}8 \\
8 \\
8 \\
8\end{array}$ & $\begin{array}{l}\text { Lifestyle } \\
\text { Sleep patterns }\end{array}$ & $\begin{array}{l}\text { Carbon Monoxide } \\
\text { Ozone }\end{array}$ & $\begin{array}{l}\text { Leadership } \\
\text { Payment systems } \\
\text { Recruitment/orientation } \\
\text { Employment security }\end{array}$ \\
\hline 7 & Health & Vibration Frequency and Intensity & \\
\hline 7 & Biorhythms & Daylight/ (Full Spectrum) Light & \\
\hline 7 & Circadian rhythms & Carbon Dioxide & \\
\hline 6 & Family status & Noise Frequency & \\
\hline 6 & Education & Oxygen & \\
\hline & $\begin{array}{l}\text { Strength/stamina } \\
\text { Attention }\end{array}$ & Light Frequency/Colour & \\
\hline $\begin{array}{c}5 \\
4\end{array}$ & SES & Noise Duration & \\
\hline 4 & Ethnicity & Lighting/Glare & \\
\hline & $\begin{array}{l}\text { Religion } \\
\text { Adaptability }\end{array}$ & Lighting/Reflections & \\
\hline & $\begin{array}{l}\text { Schemas } \\
\text { Diet }\end{array}$ & Noise Predictability/ Constancy & \\
\hline & $\begin{array}{l}\text { Agility/dexterity } \\
\text { Analytic/creative } \\
\text { Form }\end{array}$ & & \\
\hline
\end{tabular}

Note: The ranking score is calculated as the sum of the scores (0-4) allocated to each variable for each of the 4 criteria (general relevance, specific relevance, robustness and measurability). Variables in the three areas are then ordered according to this score. The shaded area shows those variables which have been included in the framework, the unshaded area those which have been rejected. 


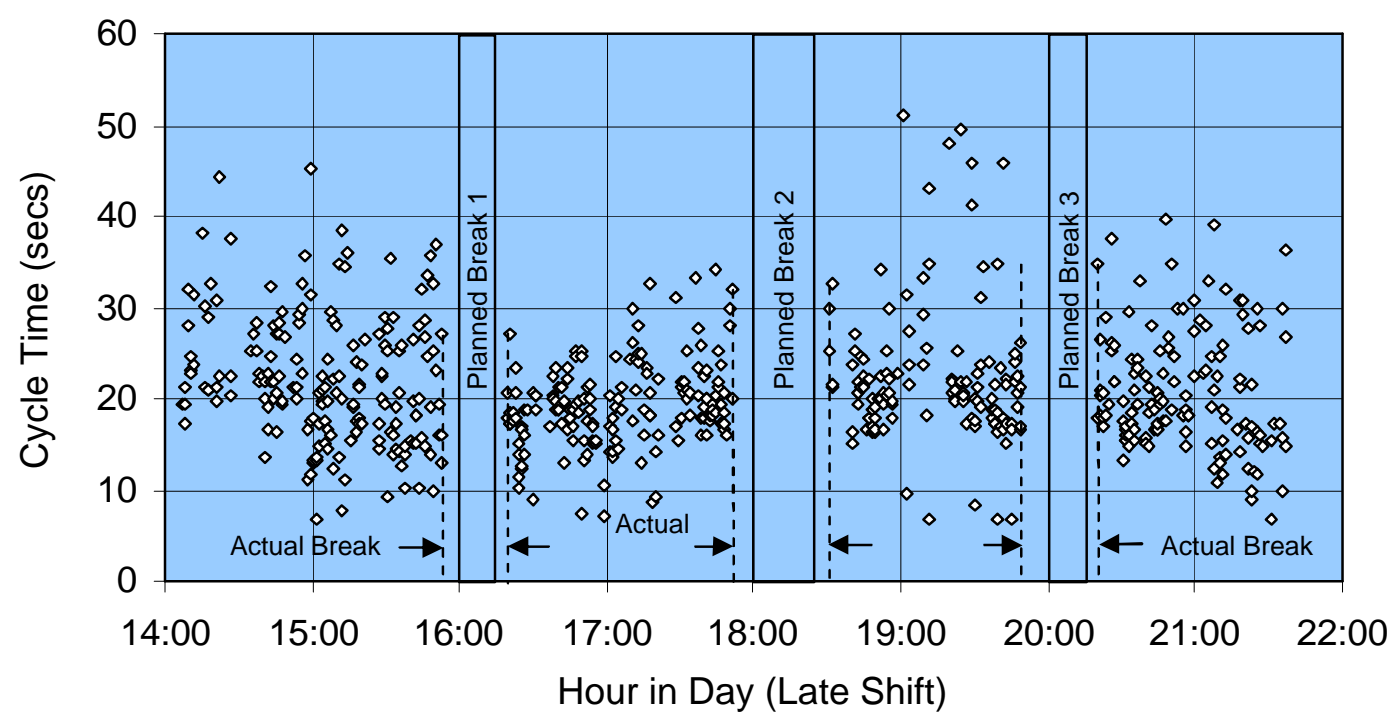

Figure 1. Actual Cycle time variations for a manual work station during an 8 hour

Note: each data point represents the actual cycle time recorded for the operation by a worker. Workers rotate approximately every hour, which means that the data points in the first hour of the shift are for a different person to those data points given in the second hour and so on throughout the eight hour period. 


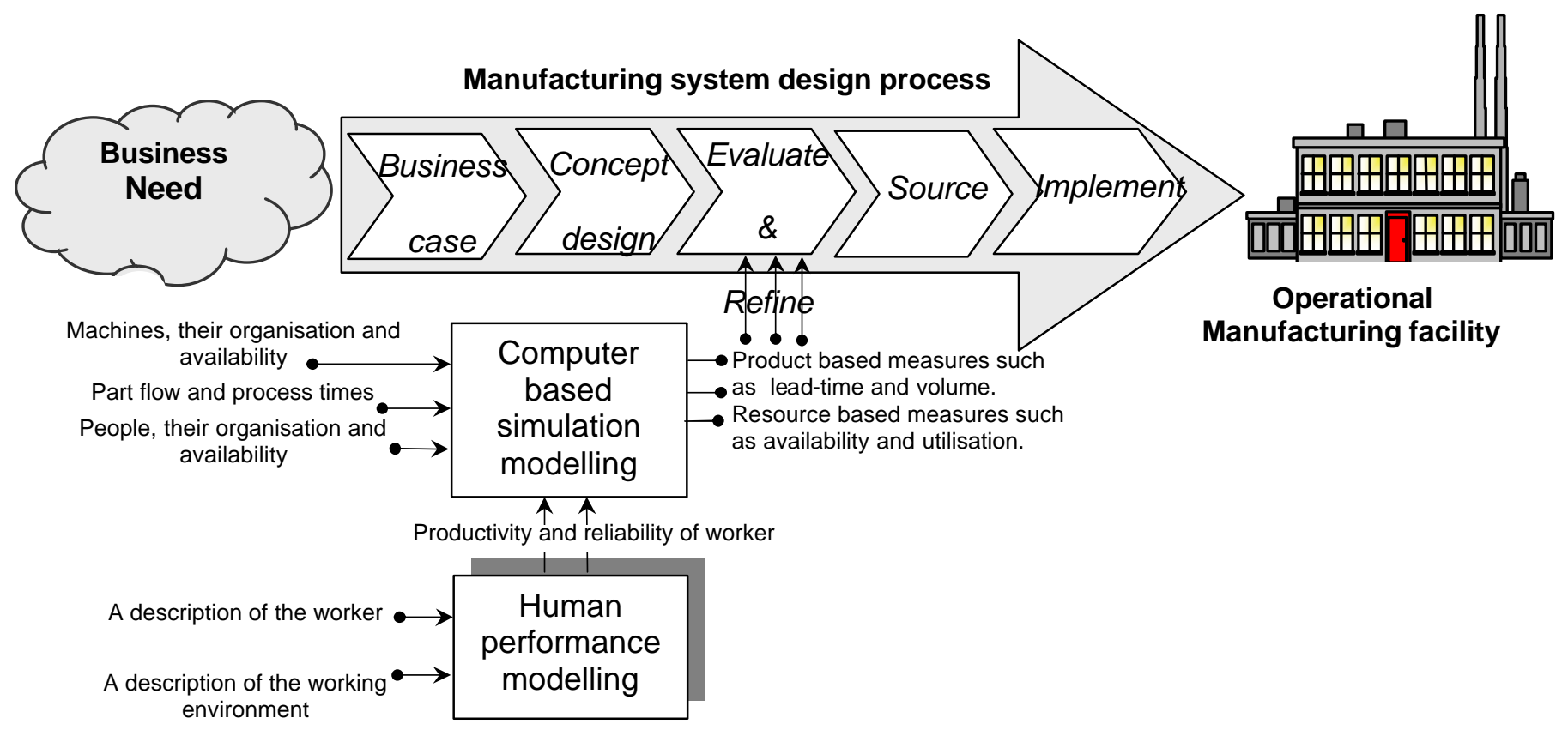

Figure 2. Human performance modelling as an aid in the manufacturing system design process, (Baines and Kay, 2002)

Description of the worker

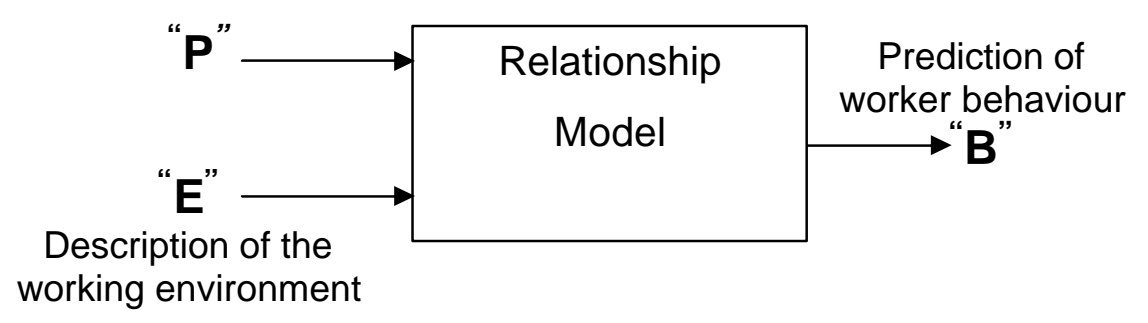

Figure 3. Lewin's dynamic theory of personality (Lewin, 1935) 
Individual

' $g$ ' (general cognitive ability)

Conscientiousness

Extroversion

Neuroticism

Organisational Commitment

Job Satisfaction

Age

Work-related Attitudes. Beliefs,

Values

Work Ethic

Goals

Agreeableness

Openness

Gender

IQ

Locus of Control

Skills level, range and experience

Physical environment

\section{Noise Level}

Air Temperature

Light Level

Humidity

Ventilation

\section{Organisational environment}

\begin{tabular}{|l|}
\hline Shift patterns \\
\hline Work teams \\
\hline
\end{tabular}

Maintenance

Training

Job rotation

Communication

Diversity

Hierarchical structure

Climate

\section{Human Performance}
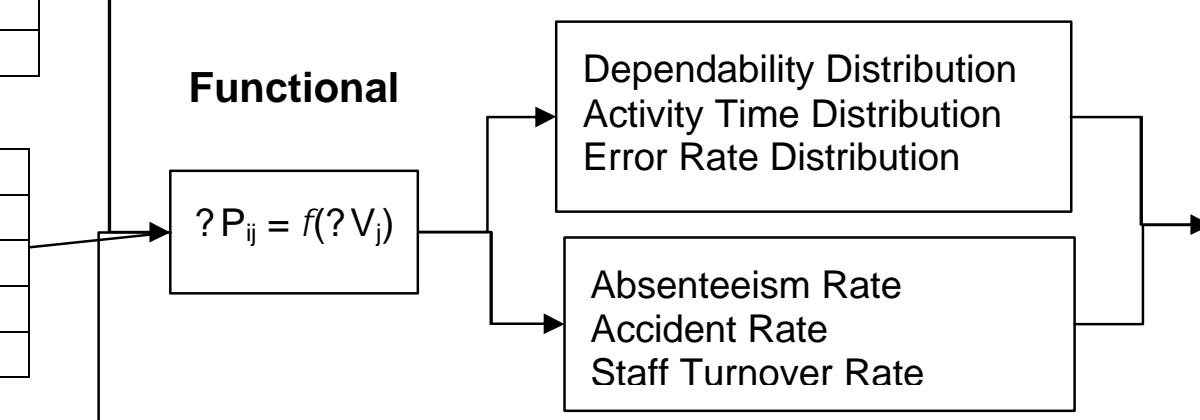

Existing DES Modelling Capability

\section{Output Variables}

Product Based Measures

(e.g. lead-time, volume)

Resource Based Measures

Simulation (e.g. availability, utilisation)
Staff Turnover Rate

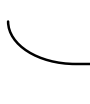

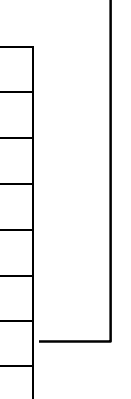

\section{HPM Capability}

Figure 4. The Human Performance Modelling Theoretical Framework 


\section{Table 1: Theoretical frameworks relating human factors and performance}

\begin{tabular}{|c|c|c|c|c|}
\hline & AUTHORS & FRAMEWORK & SYNOPSIS & TARGET APPLICATION \\
\hline 1 & Lewin, (1935) & Field theory & $\begin{array}{l}\text { Describes human behaviour as } \\
\text { determined by the interaction } \\
\text { between factors relating to the } \\
\text { individual and to the environment. }\end{array}$ & $\begin{array}{l}\text { General understanding of } \\
\text { human behaviour }\end{array}$ \\
\hline 2 & $\begin{array}{l}\text { Miller \& Swain } \\
\text { (1987) }\end{array}$ & $\begin{array}{l}\text { Performance-shaping } \\
\text { factors }\end{array}$ & $\begin{array}{l}\text { Inventory of factors that predispose } \\
\text { industrial workers to errors in } \\
\text { performance }\end{array}$ & $\begin{array}{l}\text { Human error research / } \\
\text { practice }\end{array}$ \\
\hline 3 & $\begin{array}{l}\text { Furnham } \\
\text { (1992) }\end{array}$ & $\begin{array}{l}\text { Factors predicting } \\
\text { occupational behaviour }\end{array}$ & $\begin{array}{l}\text { Specifies basic factors related to } \\
\text { occupational behaviour and their } \\
\text { interrelationships }\end{array}$ & $\begin{array}{l}\text { Research / practice } \\
\text { (general) }\end{array}$ \\
\hline 4 & $\begin{array}{l}\text { Stone \& Eddy } \\
\text { (1996) }\end{array}$ & $\begin{array}{l}\text { Factors affecting quality } \\
\text { related outcomes }\end{array}$ & $\begin{array}{l}\text { Models relationship of factors } \\
\text { pertaining to the individual and the } \\
\text { organisation }\end{array}$ & $\begin{array}{l}\text { Work improvement for } \\
\text { TQM systems }\end{array}$ \\
\hline 5 & $\begin{array}{l}\text { Dahn \& } \\
\text { Laughery } \\
\text { (1997), Bunting } \\
\text { \& Belyavin } \\
\text { (1999) } \\
\end{array}$ & $\begin{array}{l}\text { Integrated Performance } \\
\text { Modelling Environment } \\
\text { (IPME) }\end{array}$ & $\begin{array}{l}\text { Developed for modelling the human } \\
\text { contribution to system performance }\end{array}$ & $\begin{array}{l}\text { Human performance } \\
\text { modelling for military / } \\
\text { industrial application }\end{array}$ \\
\hline 6 & Das (1999) & $\begin{array}{l}\text { Comprehensive Model } \\
\text { of Industrial Work } \\
\text { Design }\end{array}$ & $\begin{array}{l}\text { Models relationships between factors } \\
\text { involving the human, machine, job, } \\
\text { workspace and work design. }\end{array}$ & Industrial work design \\
\hline 7 & $\begin{array}{l}\text { Ichniowski \& } \\
\text { Shaw (1999) }\end{array}$ & $\begin{array}{l}\text { Human Resource } \\
\text { Management (HRM) } \\
\text { practices and } \\
\text { productivity }\end{array}$ & $\begin{array}{l}\text { A set of human resource } \\
\text { management (HRM) techniques } \\
\text { typical of Japanese manufacturing } \\
\text { firms (job rotation, communication, } \\
\text { orientation, payment systems, teams, } \\
\text { recruitment/screen }\end{array}$ & $\begin{array}{l}\text { Overall productivity of } \\
\text { Japanese and US steel } \\
\text { finishing plants }\end{array}$ \\
\hline 8 & $\begin{array}{l}\text { Bonney, Head, } \\
\text { Ratchev \& } \\
\text { Moualek (2000) }\end{array}$ & $\begin{array}{l}\text { Manufacturing System } \\
\text { Design Framework for } \\
\text { Computer Aided } \\
\text { Industrial Engineering }\end{array}$ & $\begin{array}{l}\text { Integrates product, process and } \\
\text { system design by emphasizing } \\
\text { human factors considerations }\end{array}$ & $\begin{array}{l}\text { Manufacturing systems } \\
\text { computer based design } \\
\text { software }\end{array}$ \\
\hline 9 & Schmidt (2000) & $\begin{array}{l}\text { Physical conditions, } \\
\text { Emotional state, } \\
\text { Cognitive capabilities, } \\
\text { Social status (PECS) }\end{array}$ & $\begin{array}{l}\text { Agent based modelling framework } \\
\text { Physical, Emotional, Cognitive and } \\
\text { Social effects group performance }\end{array}$ & $\begin{array}{l}\text { Human performance } \\
\text { modelling of social } \\
\text { systems }\end{array}$ \\
\hline 10 & $\begin{array}{l}\text { Parker, Wall \& } \\
\text { Cordery (2001) }\end{array}$ & $\begin{array}{l}\text { Elaborated Model of } \\
\text { Work Design }\end{array}$ & $\begin{array}{l}\text { Specifies five categories of work } \\
\text { design variables that span individual, } \\
\text { group and organizational variables }\end{array}$ & $\begin{array}{l}\text { Contemporary work } \\
\text { design }\end{array}$ \\
\hline 11 & $\begin{array}{l}\text { Toriizuka } \\
\text { (2001) }\end{array}$ & $\begin{array}{l}\text { Performance-shaping } \\
\text { factors for industrial } \\
\text { plant maintenance }\end{array}$ & $\begin{array}{l}\text { Inventory of factors that influence } \\
\text { human reliability, work efficiency and } \\
\text { workload }\end{array}$ & $\begin{array}{l}\text { Work improvement of } \\
\text { maintenance tasks in } \\
\text { industrial plants }\end{array}$ \\
\hline
\end{tabular}


Table 2: Selection of key human centered factors affecting worker performance

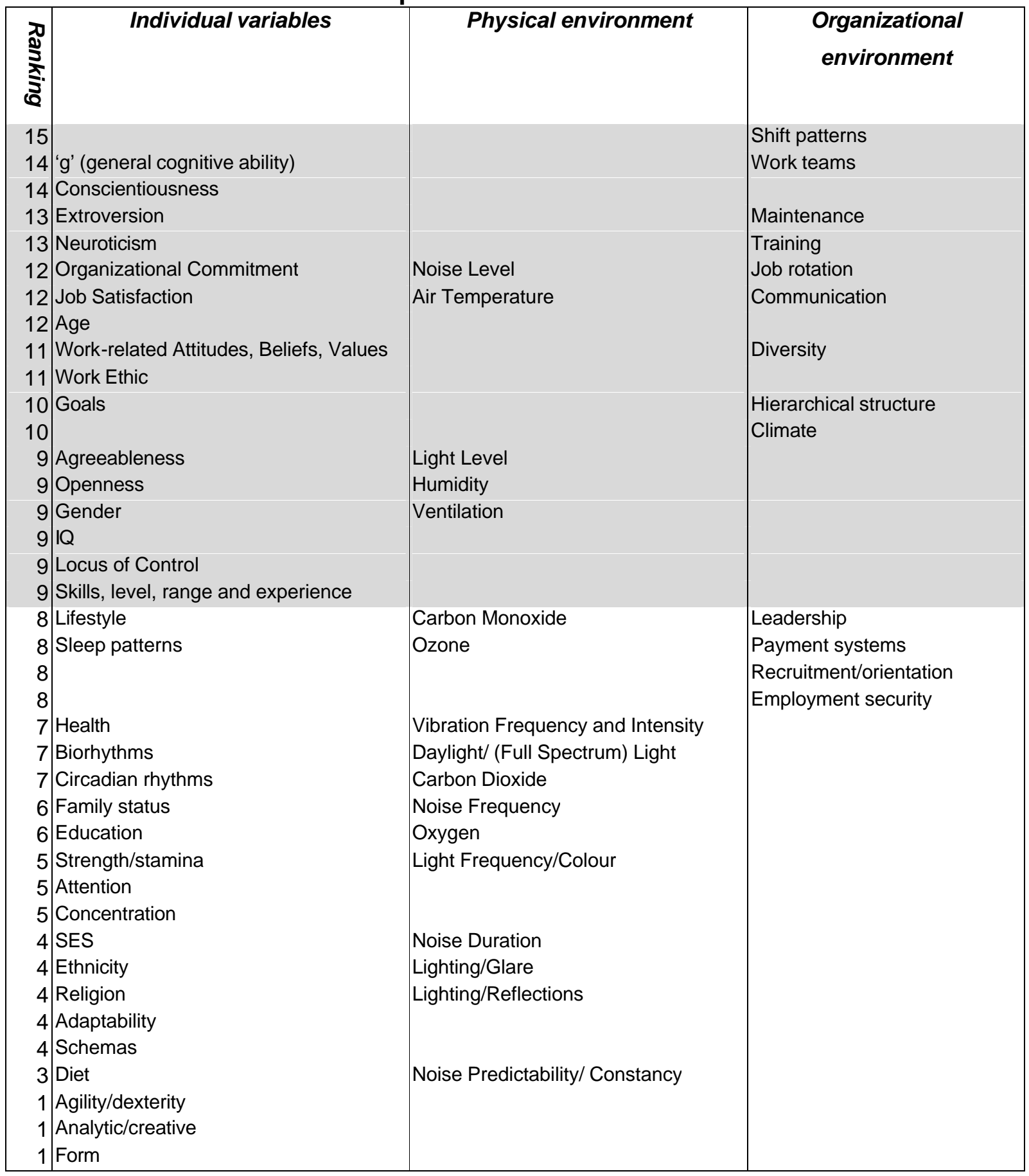

Note: The ranking score is calculated as the sum of the scores (0-4) allocated to each variable for each of the 4 criteria (general relevance, specific relevance, robustness and measurability). Variables in the three areas are then ordered according to this score. The shaded area shows those variables which have been included in the framework, the unshaded area those which have been rejected. 


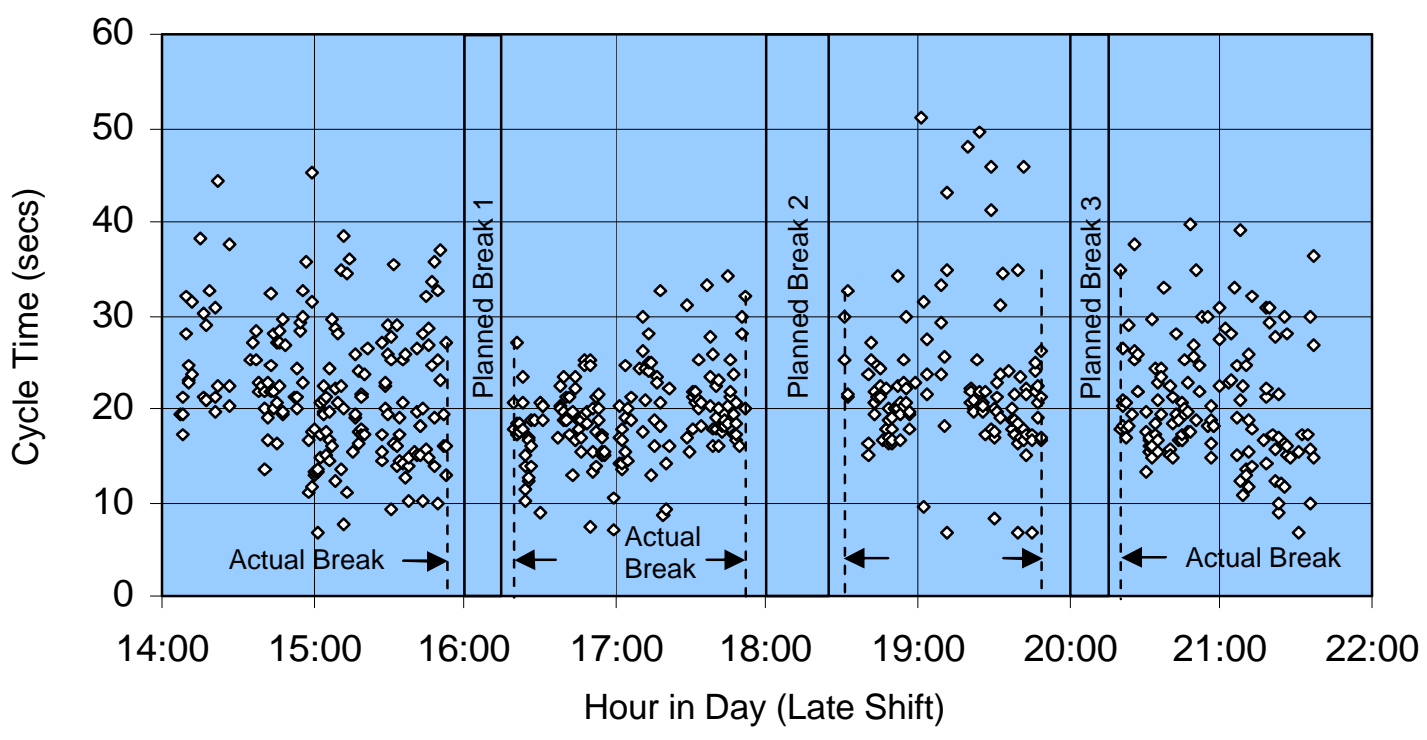

Figure 1. Actual Cycle time variations for a manual work station during an 8 hour production period

Note: each data point represents the actual cycle time recorded for the operation by a worker. Workers rotate approximately every hour, which means that the data points in the first hour of the shift are for a different person to those data points given in the second hour and so on throughout the eight hour period. 


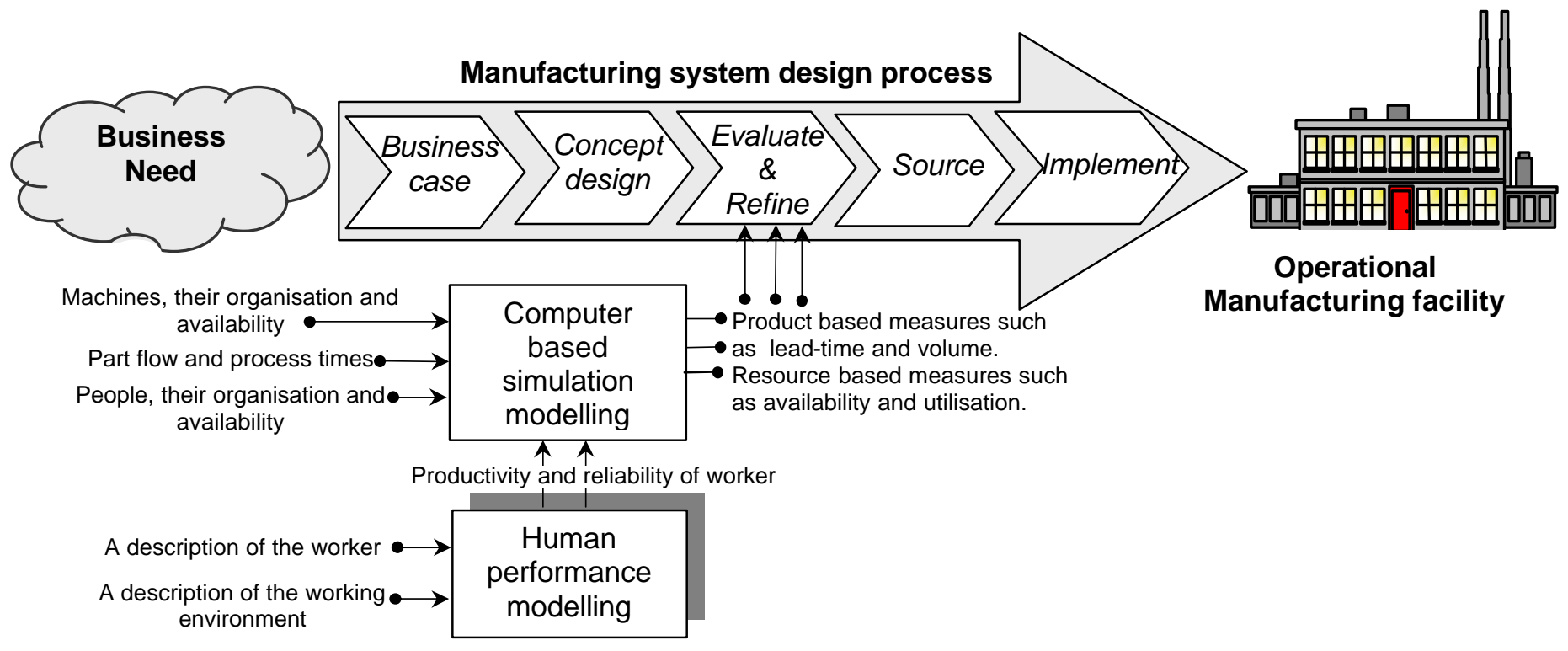

Figure 2. Human performance modelling as an aid in the manufacturing system design process, (Baines and Kay, 2002)

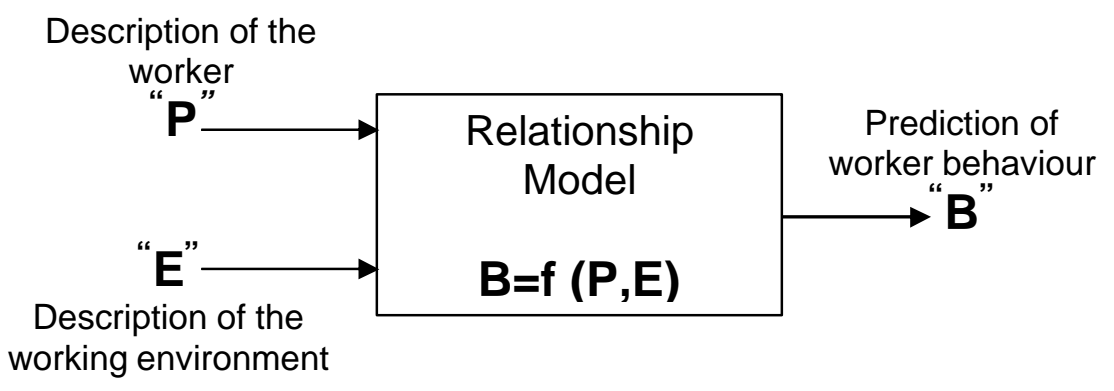

Figure 3. Lewin's dynamic theory of personality (Lewin, 1935) 



\section{Key Human Centred Factors}

\section{Individual}

\begin{tabular}{|l|}
\hline 'g' (general cognitive ability) \\
\hline Conscientiousness \\
\hline Extroversion \\
\hline Neuroticism \\
\hline Organisational Commitment \\
\hline Job Satisfaction \\
\hline Age \\
\hline Work-related Attitudes. Beliefs, Values \\
\hline Work Ethic \\
\hline Goals \\
\hline Agreeableness \\
\hline Openness \\
\hline Gender \\
\hline IQ \\
\hline Locus of Control \\
\hline Skills level, range and experience \\
\hline
\end{tabular}

\section{Physical environment}

\begin{tabular}{|l|}
\hline Noise Level \\
\hline Air Temperature \\
\hline Light Level \\
\hline Humidity \\
\hline Ventilation \\
\hline
\end{tabular}

\section{Organisational environment}

\begin{tabular}{|l|}
\hline Shift patterns \\
\hline Work teams \\
\hline Maintenance \\
\hline Training \\
\hline Job rotation \\
\hline Communication \\
\hline Diversity \\
\hline Hierarchical structure \\
\hline Climate \\
\hline
\end{tabular}

\section{Human Performance} Variation Metrics

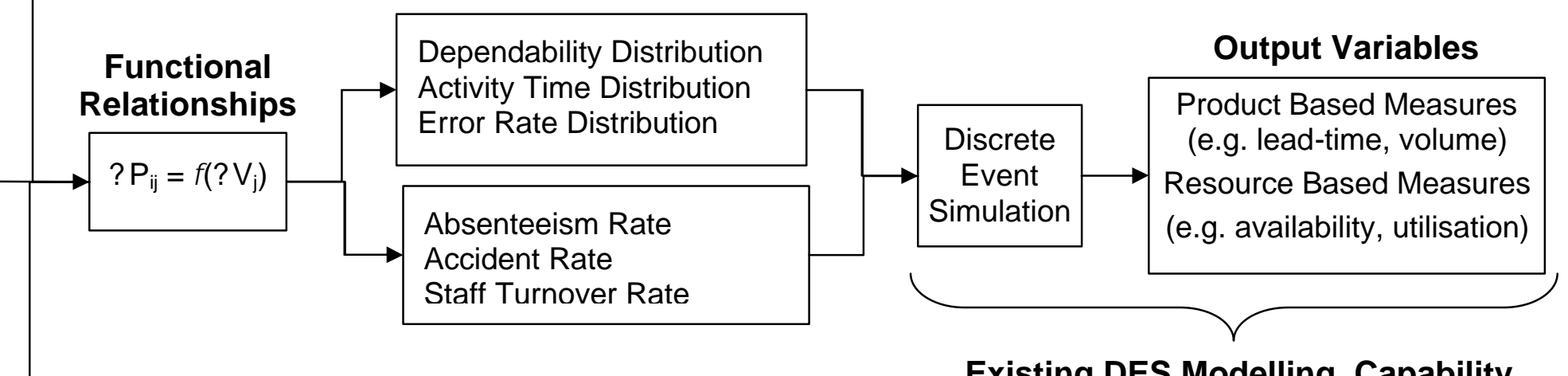

\section{HPM Capability}

Figure 4. The Human Performance Modelling Theoretical Framework 